\title{
Animal Board Invited Review: Sheep birth distribution in past herds: a review for prehistoric Europe (6th to 3rd millennia BC)
}

\author{
M. Balasse ${ }^{1 \dagger}$, A. Tresset $^{1}$, A. Bălăşescu ${ }^{2}$, E. Blaise ${ }^{1 \mathrm{a}}$, C. Tornero $^{1 \mathrm{~b}}, \mathrm{H}$. Gandois $^{3}$, D. Fiorillo ${ }^{1}$, \\ É. Á. Nyerges ${ }^{4}$, D. Frémondeau ${ }^{5,6}$, E. Banffy ${ }^{4,7}$ and M. Ivanova ${ }^{8}$ \\ ${ }^{1}$ UMR 7209 Archéozoologie, archéobotanique: sociétés, pratiques, environnements, Sorbonne Universités, CNRS-MNHN, 55 rue Buffon, 75005 Paris, France; \\ ${ }^{2}$ National Museum of Romanian History, 12 Calea Victoriei, Sector 3, 030026 Bucharest, Romania; ${ }^{3}$ UMR 8215 Trajectoires, De la sédentarisation à I'Etat, Maison de \\ I'Archéologie et de l'Ethnologie, 21 allée de l'Université, 92023 Nanterre, France; ${ }^{4}$ Institute of Archaeology, Research Centre for the Humanities, Hungarian Academy \\ of Sciences, 1014 Budapest, Úri 49, Hungary; ${ }^{5}$ CAS, Geo Instituut, KU Leuven, Celestijnenlaan 200E, Box 2408, 3001 Leuven, Belgium; ${ }^{6}$ Department of Biology, \\ University of Leuven, C. Deberiotstraat 32, 3000 Leuven, Belgium; ${ }^{7}$ Römisch-Germanische Kommission des Deutschen Archäologischen Instituts, 60325 Frankfurt, \\ Germany; ${ }^{8}$ Institut für Ur-und Frühgeschichte und Vorderasiatische Archäologie, Universität Heidelberg, 69117 Heidelberg, Germany
}

(Received 5 October 2016; Accepted 27 March 2017; First published online 23 May 2017)

In temperate latitudes sheep have a seasonal reproductive behaviour, which imposes strong constraints on husbandry in terms of work organization and availability of animal products. During the last 50 years, researchers have focused on understanding the mechanisms driving small ruminants' reproduction cycles and finding ways to control them. This characteristic is inherited from their wild ancestor. However, the history of its evolution over the 10 millennia that separates present day European sheep from their Near Eastern ancestors' remains to be written. This perspective echoes archaeologists' current attempts at reconstructing ancient pastoral societies' socio-economical organization. Information related to birth seasonality may be retrieved directly from archaeological sheep teeth. The methodology consists of reconstructing the seasonal cycle record in sheep molars, through sequential analysis of the stable oxygen isotope composition $\left(\delta^{18} \mathrm{O}\right)$ of enamel. Because the timing of tooth development is fixed within a species, inter-individual variability in this parameter reflects birth seasonality. A review of the data obtained from 10 European archaeological sites dated from the 6 th to the $3 \mathrm{rd}$ millennia $B C$ is provided. The results demonstrate a restricted breeding season for sheep: births occurred over a period of 3 to 4 months, from late winter to early summer at latitudes $43^{\circ} \mathrm{N}$ to $48^{\circ} \mathrm{N}$, while a later onset was observed at a higher latitude $\left(59^{\circ} \mathrm{N}\right)$. All conclusions concurred with currently held expectations based on present day sheep physiology, which, aside from the historical significance, contributes to the reinforcing of the methodological basis of the approach. Further study in this area will permit regional variability attributable to technical choices, within global schemes, to be fully reported.

Keywords: sheep, breeding seasonality, zooarchaeology, biogeochemistry, tooth enamel

\section{Implications}

Sheep are seasonal breeders. Although this characteristic is admittedly inherited from their ancestor, the Oriental Mouflon (Ovis orientalis Gmelin 1774) for the Western Eurasiatic sheep, the history of its evolution over 10 millennia of domestication still needs to be documented; our method was developed to attain this goal. The biogeochemical

\footnotetext{
a Present address: Labex ARCHIMEDE, program IA-ANR-11-LABX-0032-01, UMR 5140, Archéologie des Sociétés Méditerranéennes, Université Paul Valéry, Montpellier 3, 390 avenue de Pérols, F-34970 Lattes, France.

b Present address: Institut Català de Paleoecologia Humana i Evolució Social (IPHES), C/Marcel.lí Domingo s/n, Campus Sescelades URV (Edifici W3), 43007 Tarragona, Spain.

${ }^{\dagger}$ E-mail: balasse@mnhn.fr
}

composition of enamel retains a record of the seasonal cycle during tooth formation, which can be retrieved from archaeological sheep teeth and used to infer their seasonality and season of birth. The investigation of European sheep teeth of between 8000 and 5000 years old lays the foundation for research that will link present day sheep to their earliest domestic ancestors.

\section{Introduction}

In temperate latitudes, sheep have a seasonal reproductive behaviour. On an annual scale, they alternate between a period of sexual activity and a period of sexual rest, with no behavioural or ovarian activity in the ewe (Hafez, 1952) 
and dramatically reduced sperm production in the male (Dacheux et al., 1981). This cycle, modulated by melatonin secretion, is under strong photoperiodic control (Karsch et al., 1984; Malpaux et al., 1997; Thiéry et al., 2002). In Europe, most domestic sheep breeds have a breeding season from late summer to early winter, leading to births occurring 5 months later from winter to early summer. This characteristic imposes strong constraints on husbandry, in terms of work organization and seasonal availability of animal products (Chemineau et al., 2008). Researches in animal agriculture over the last 50 years have focused on understanding the physiological and environmental mechanisms driving this cycle, and trying to find ways to control it using hormonal treatments, exposure to artificial light regimens or through the manipulation of socio-sexual signals - the male effect (Thimonier, 1981; Martin et al., 1986).

These recent advances have revolutionized the tempo of multimillenary small ruminant husbandry system. Over 10500 years of manipulation separates today's European domestic sheep breeds from their wild ancestors, during which time population redistributions, management of demography and diet, and adaptation to economic rules have modified their ancestral heritage (Hafez, 1952). In spite of this, small ruminants have retained seasonal breeding behaviour, although differences have been observed between present day sheep breeds with a regionally focused history (Hafez, 1952; Thimonier and Mauléon, 1969). Reconstructing the history of sheep breeding seasonality over a long time scale, starting with the unimproved domestic herds from prehistory, could assist with a better understanding of the reasons for the retention of this characteristic and its variability over millennia of domestication.

This perspective echoes archaeologists' current considerations. European sheep (Ovis aries) lineages originated in the Near East (Poplin, 1979). Zooarchaeology and population genetics (Handley et al., 2007) have demonstrated that the sheeps' wild ancestor ( 0 . orientalis - absent from Europe) was initially domesticated in southeastern Anatolia, The earliest evidence of morphologically modified sheep dates to $8500 \mathrm{BC}$, as a result of man's increasing control over wild animals that probably started several centuries earlier (Peters et al., 2005; Meadows et al., 2007; Vigne et al., 2012). Domestic sheep lineages were introduced to Europe through Greece and the Balkans in the early 7th millennium BC. From there, they spread along the northern coastline of the Mediterranean and inland Europe through the Danubian corridor and adjacent rivers, to reach the coasts of northwestern Europe by $5000 \mathrm{BC}$. They eventually colonized the British Isles at the start of the 4th millennium BC (Tresset and Vigne, 2011). Along this westward and northward diffusion, sheep adapted to a diversity of climates and landscapes across a wide latitudinal gradient. Strong environmental constraints may have had definitive bearings on early European husbandry, some of which influenced the reproductive cycle of domestic animals. As now, the timing and the length of the lambing season constituted key parameters of ancient husbandry. Although economic issues were different in terms of the market, constraints at a husbandry system scale were probably just as strong with regards to the organization of agro-pastoral tasks, the availability of animal production on a seasonal scale and residential strategy (Digard, 1981; Balasse and Tresset, 2007).

Across prehistoric Europe, it is reasonable to consider that in early domestic animals, births were restricted to a defined period of the year. The objective of this research is not to confirm the seasonality of births in early European domestic sheep, but to define the duration of this period and determine the time of year they occurred. This could, hopefully, lead to a clearer picture of seasonal rhythms and associated socio-economical constraints affecting early husbandry systems, including variability at a regional and interregional scale. In this study, we recall the methodological steps that led to the elaboration of a procedure to determine birth seasonality in past sheep herds, from the analysis of the stable oxygen isotoe composition of tooth enamel. We then provide a review of the data from European archaeological contexts dated to the 6 th to the 3rd millennia BC (calibrated dates). This set of sites located under contrasted latitudes $\left(43^{\circ} \mathrm{N}\right.$ to $46^{\circ} \mathrm{N}$ and $\left.59^{\circ} \mathrm{N}\right)$ also provides an interesting case for observation, due to the photoperiodic control on sheep reproductive activity and the latitudinal variation of this parameter (Hafez, 1952).

\section{Material and methods}

\section{Principles of the sequential stable oxygen isotope analysis in tooth enamel}

Stable oxygen isotope ratios $\left(\delta^{18} 0\right)$ from the mineral fraction of vertebrate skeleton are linked to that of body water, derived from ingested water, whose primary source is precipitation (Land et al., 1980; D'Angela and Longinelli, 1990). The precipitation $\delta^{18} 0$ values are affected by ambient temperature and its seasonal variations. At high and middle latitudes in Europe, the highest $\delta^{18} 0$ values of precipitation occur during the warmest season and the lowest during the coldest season (Rozanski et al., 1993). During formation, teeth build and retain a chronological record of the individual's stable isotope history. This history may be reconstructed through sequential sampling of dental tissues following growth directions (Figure $1 \mathrm{a}$ ). In particular, $\delta^{18} 0$ sequences have been retrieved from enamel, showing cyclical variations reflecting seasonal trends (Figure $1 \mathrm{~b}$ ).

Because the timing of tooth growth is fixed within a species, inter-individual variability in the $\delta^{18} 0$ sequences retrieved from enamel (Figure 1c) is related to variability in the season of birth (Bryant et al., 1996; Fricke and O'Neil, 1996). This variability may be described through the observation of the position of the optimum value of the $\delta^{18} 0$ cycle in the tooth crown (Balasse et al., 2003). A quantitative estimation of the variability involves a normalization procedure, where the $\delta^{18} 0$ sequences are modelled using an equation derived from a cosine function (Balasse et al., 2012b). This allows to objectively define the position of the 
(a)

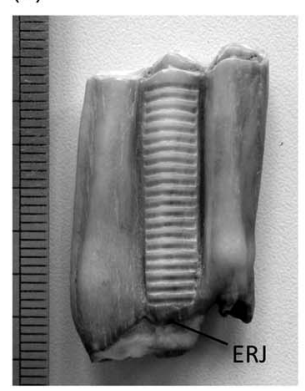

(b)

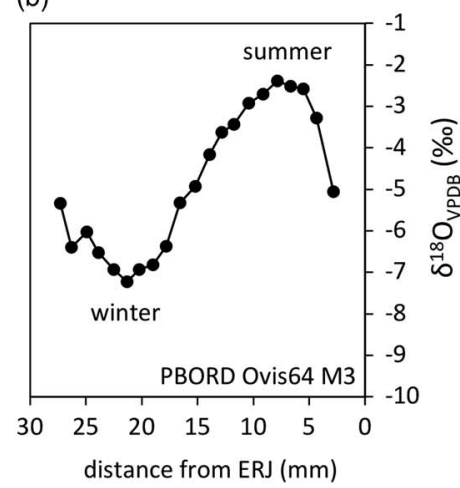

(c)

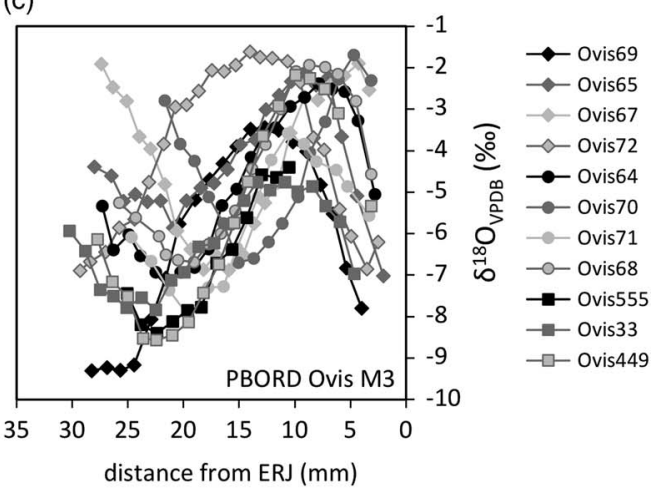

Figure 1 Description of the methodological approach: enamel sequential sampling of a sheep's lower third molar (a), retrieval of the seasonal cycle in the sequence of $\delta^{18} 0$ values; measured against Vienna Pee Dee Belemnite (VPDB) (b) and comparison of inter-individual variability (c). Example from the Chalcolithic site of Borduşani-Popină. Samples are located in the tooth crown using their distance from the enamel root junction (ERJ).

optimum value and to determine the period of the cycle (the distance over which the isotopic record covers one annual cycle), which may be used to link distance to time (Supplementary Figure S1a). The period of the cycle is then used to normalize the position of the optimum in the tooth crown, in order to eliminate the tooth size factor (Supplementary Figure S1b).

The birth season is determined by comparison with modern reference sets, assuming a similar timing of tooth development for modern and ancient sheep breeds. In sheep, these include the Carmejane (CAR) reference set for late winter and late summer births (Blaise and Balasse, 2011) and the Rousay (ROU) reference set for mid-spring births (Balasse et al., 2012b). Analyses are conducted on the second (M2) and the third molars (M3).

\section{The archaeological data set}

The archaeological assemblages (Figure 2 and Table 1) belong to central and southeastern Europe (early 6th to second half of 5th millennium BC), France (Middle and Late Neolithic, 4th and 3rd millennia BC) and the Northern Isles of Scotland (Orkney, first half of 4 th to mid 3rd millennium BC). A brief description of all animal husbandry contexts and orientations are provided in Supplementary Material S1. Several millennia separate these husbandry systems from the earliest times of domestication. Similar studies were recently initiated on earlier Near Eastern sites but are still at a preliminary state (Tornero et al., 2016).

\section{The modern reference sets}

The ROU is composed of the lower M2 from sheep from a Shetland cross, raised on a working farm on the island of Rousay in Orkney (Figure 2). They provide a reference for April/May births (Balasse et al., 2012b). The CAR is composed of five M2s from Préalpes du Sud ewes raised on an experimental farm in southern France (Digne, Alpes de Haute Provence, Figure 2). They provide references for late January/ early February births and September births (Blaise and Balasse, 2011).
An additional reference set was introduced to this study, composed of three sheep from a Ouessant $\times$ Landes de Bretagne cross, raised on the island of Kemenez (KMZ; Molène, Finistère) (Figure 2). Uncontrolled reproduction leads to lambing which occur almost exclusively in February. The specimens composing the data set were retrieved from the semi-articulated skeletons of individuals who had died of natural causes, collected on the shoreline of the island in 2013 and 2014. The stable isotope data set is currently under constitution; in this study we include the first results obtained from three M2s and one M3 (Table 2).

In all locations, the $\delta^{18} 0$ values of modern precipitation are driven by ambient temperature as the main factor, and show similar patterns of seasonal variation, with the highest values measured in July/August (IAEA/WMO, 2016).

\section{Analytical protocol}

Enamel samples were drilled (Balasse et al., 2003), on the posterior (M2), middle (lower M3) or anterior lobe (upper M3). The archaeological enamel powders were pre-treated for elimination of diagenetic carbonates following Tornero et al. (2013). Isotope ratios were measured on a DeltaVAdvantage MS interfaced with a Kiel IV device (Thermo Scientific, Bremen, Germany). The analytical precision within each run, estimated from repeated analyses of our laboratory carbonate standard (Marbre LM, normalized to NBS19) was lower than $0.06 \%$ o $(n=8)$. The modelling procedure was applied to the data sets from KMZ, CTD, CR, HPWN, KH, SKB, PBORD, HVA and ALS (Table 1) following Balasse et al. (2012b). The data set from Cheia (CHE) (Tornero et al., 2013) was revised in order to correct the estimation of the location of the enamel root junction in teeth where mineralization was incomplete.

\section{Results}

The distribution of births within the archaeological sheep, as investigated from the modelled $\delta^{18} 0$ sequences, is shown in Figures 3 (M2) and 4 (M3). Results from the stable isotope analysis and modelling are presented extensively in the 


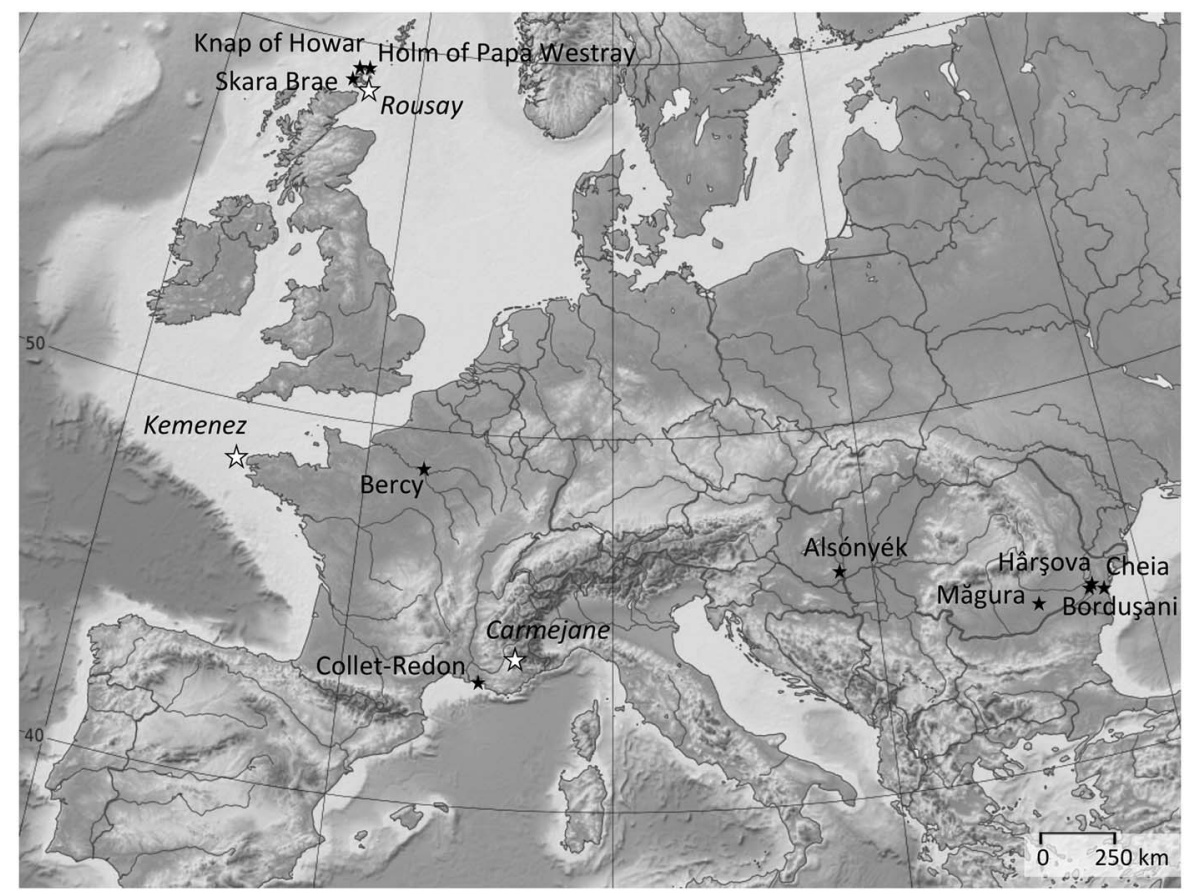

Figure 2 Location of the archaeological sites where sheep birth distribution was investigated $(\star)$ and modern farms which provided reference sheep with known birth season as comparative material (访).

Table 1 List of archaeological sites providing sheep teeth included in the study

\begin{tabular}{|c|c|c|c|}
\hline Site (abbreviation) & Location (latitude) & Chronology (date ${ }^{1}$ ) & $\delta^{18} 0^{2}$ \\
\hline Măgura (MAG) & Romania $\left(43^{\circ} \mathrm{N}\right)$ & Early Neolithic (6th mil.) & 1 \\
\hline Alsónyék (ALS) & Hungary $\left(46^{\circ} \mathrm{N}\right)$ & Early Neolithic (6th mil.) & 8 \\
\hline Cheia (CHE) & Romania $\left(44^{\circ} \mathrm{N}\right)$ & Chalcolithic (5th mil.) & 3 \\
\hline Borduşani (ALS) & Romania $\left(44^{\circ} \mathrm{N}\right)$ & Chalcolithic (5th mil.) & 7 and 8 \\
\hline Hârşova (HVA) & Romania $\left(44^{\circ} \mathrm{N}\right)$ & Chalcolithic (5th mil.) & 7 and 8 \\
\hline Bercy (BQS) & France $\left(48^{\circ} \mathrm{N}\right)$ & Middle Neolithic (4th mil.) & 2 \\
\hline Knap of Howar (KH) & Orkney $\left(59^{\circ} \mathrm{N}\right)$ & Middle Neolithic (4th to 3rd mil.) & 5 and 6 \\
\hline Collet-Redon (CR) & France $\left(44^{\circ} \mathrm{N}\right)$ & Late Neolithic (4th/3rd mil.) & 4 \\
\hline Skara Brae (SKB) & Orkney $\left(59^{\circ} \mathrm{N}\right)$ & Late Neolithic (3rd mil.) & 8 \\
\hline Holm of Papa Westray (HPWN) & Orkney $\left(59^{\circ} \mathrm{N}\right)$ & Late Neolithic (3rd mil.) & 5 and 6 \\
\hline
\end{tabular}

mil. = millennium.

${ }^{1}$ Calibrated BC.

${ }^{2}$ Original $\delta^{18} 0$ data set published in 1: Balasse et al. (2013); 2: Balasse et al. (2012a); 3: Tornero et al. (2013); 4: Blaise and Balasse (2011); 5: Balasse et al. (2006); 6: Balasse and Tresset (2009); 7: Balasse et al. (2017); 8: this study.

Table 2 The modern sheep reference sets

\begin{tabular}{|c|c|c|c|c|}
\hline Reference set & Location (latitude) & Breed & Date of birth & $\delta^{18} 0^{1}$ \\
\hline Carmejane & France $\left(44^{\circ} \mathrm{N}\right)$ & Préalpes du Sud & January to February and September & 1 \\
\hline Rousay & Orkney $\left(59^{\circ} \mathrm{N}\right)$ & Shetland cross & April to May & 2 \\
\hline Kemenez & Britanny $\left(48^{\circ} \mathrm{N}\right)$ & Ouessant $\times$ LDB & February & 3 \\
\hline
\end{tabular}

$\mathrm{LDB}=$ Landes de Bretagne.

${ }^{1}$ Original $\delta^{18} 0$ data set published in 1: Blaise and Balasse (2011); 2: Balasse et al. (2012a); 3: Tornero et al. (2013).

Supplementary Tables $\mathrm{S} 1$ and $\mathrm{S} 2$ and Supplementary Figures S1 to S6. In all instances, seasonal breeding is confirmed. Globally, in all assemblages from central/southeastern Europe (latitudes $43^{\circ} \mathrm{N}$ to $46^{\circ} \mathrm{N}$ : Măgura, Alsónyék, Cheia, Borduşani and Hârşova) the period of sheep births occurred at the same time of the year and over a comparable duration $\left(x_{0} / X\right.$ ratios ranging from 0.09 to 0.61 in the M3; Figure 4). The sheep from Collet-Redon $\left(44^{\circ} \mathrm{N}\right)$ and Bercy $\left(48^{\circ} \mathrm{N}\right)$ in France also belong to this group: the births observed at these sites occurred within the same time period as in Cheia 


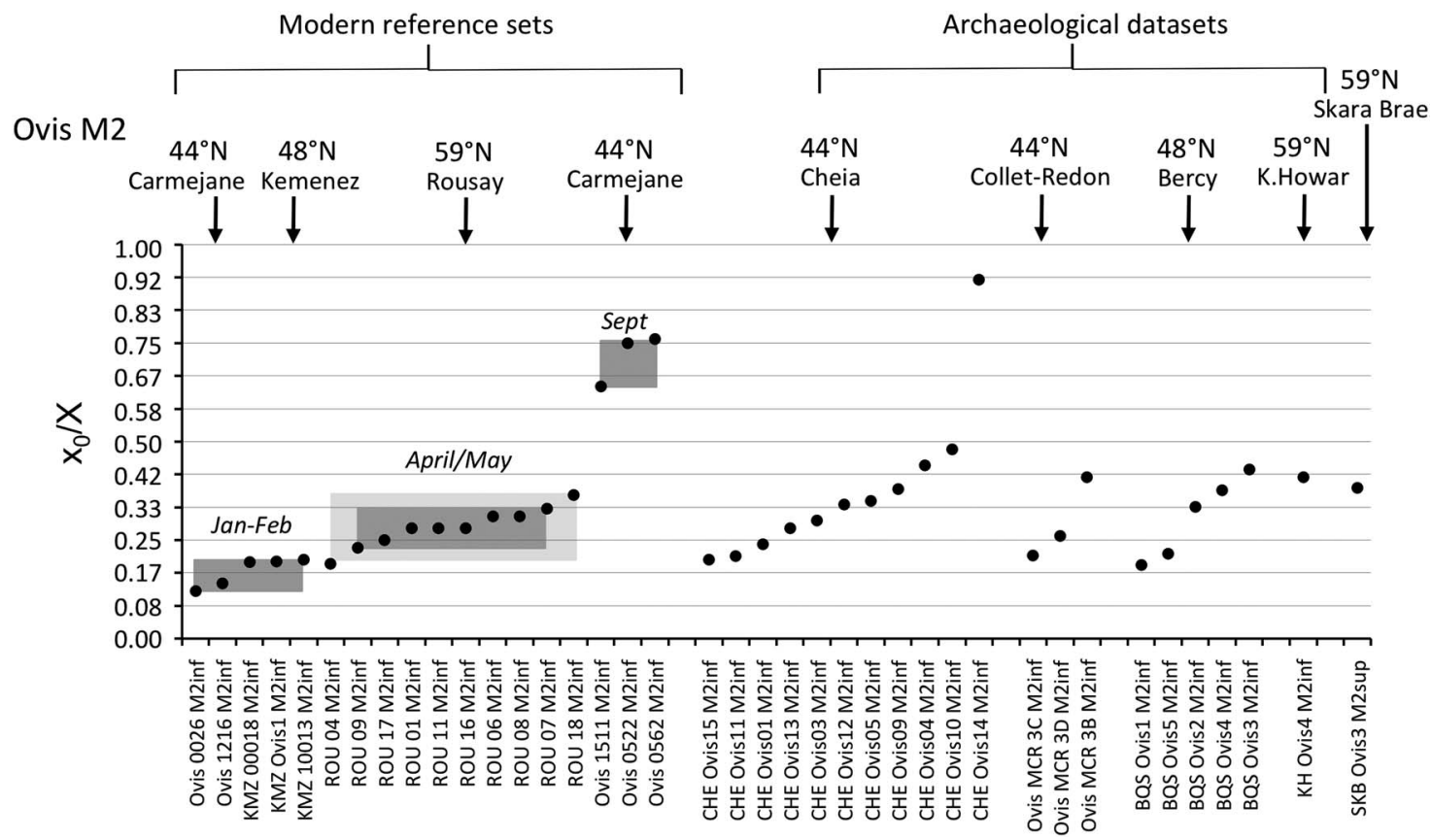

Figure 3 Results from normalization of the position in the M2 crown of the highest $\delta^{18} 0$ value $\left(x_{0}\right)$, using the period $(X)$ of the cycle. Comparison of the archaeological data sets with the modern reference sets. For the Rousay reference, the rectangles indicate the whole variability (light grey) and 1 SD around the mean ( $1 \sigma$; dark grey). Data: see Tables 1 and 2 . ROU = Rousay; CHE = Cheia; BQS = Bercy; KH = Knap of Howar; SKB = Skara Brae.

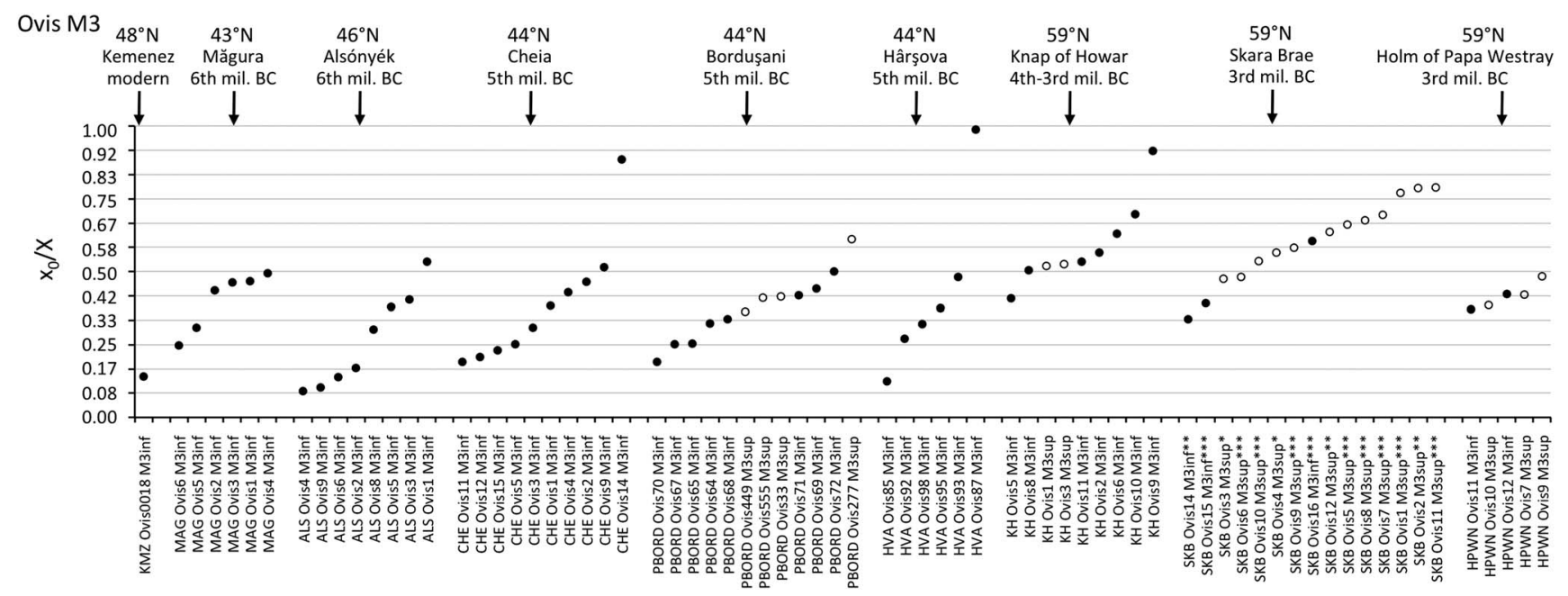

Figure 4 Results from normalization of the position in M3 crown of the highest $\delta^{18} 0$ value $\left(x_{0}\right)$, using the period $(X)$ of the cycle. The dark symbol refers to lower M3, the open symbols refer to upper M3. Skara Brae: first occupation phase $\left({ }^{*}\right)$; start of second occupation phase $\left({ }^{* *}\right)$, end of second occupation

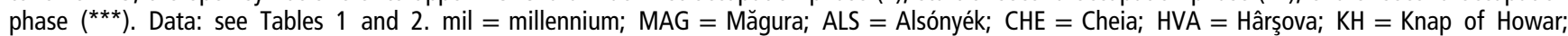
SKB = Skara Brae; HPWN = Holm of Papa Westray.

(Figure 3). Two outliers to this middle latitudes group are observed, at Cheia $\left(x_{0} / X\right.$ ratio $=0.88$ on the $\left.\mathrm{M} 3\right)$ and Hârşova (0.99) (Figure 4).

By contrast to the group of middle latitude sites, the Orkney sites (latitude $59^{\circ} \mathrm{N}$ ) showed a delayed onset of the breeding season, as reflected in significantly higher $x_{0} / X$ ratios (Wilcoxon rank test, $W=197.5, P=2.10^{-6}$ ), globally ranging between 0.34 and 0.79 on the M3 (Figure 4). The difference remains highly significant (Wilcoxon rank test, $W=94.5, P=0.0025)$ when considering lower teeth in isolation. A delayed onset of the breeding season in Orkney is also supported by the results obtained on the $\mathrm{M} 2$, where the births at Skara Brae and Knap of Howar occurred within the latest observed at the middle latitude sites of Cheia, Bercy and Collet-Redon (Figure 3).

Results from the modern sheep molars confirm and enlarge the previous reference data sets (Figure 3 ). A difference of 6.2 months ( 0.52 in $x_{0} / X$ ratios, i.e. $52 \%$ of a year) is observed between the KMZ and the CAR sheep born 7 months apart; the KMZ sheep (February births) yielded slightly higher $x_{0} / X$ ratios than those measured in the CAR sheep (late January/early February). A slight disagreement 
appears between the KMZ (February) and ROU (late April/ early May) data sets, separated on average by only 1 month when a larger difference would be expected. The $x_{0} / X$ ratio measured on the KMZ M3 at 0.14 provides the first reference point for the record of a winter birth in the third molar (Figure 4).

\section{Discussion}

Sheep births distribution in the archaeological contexts All results indicate seasonal breeding in archaeological sheep. The duration of the period of births is estimated to $\sim 3$ to 4 months (Figures 3 and 4). This is significantly higher than what is observed today in the European mouflon, where births occur during a period of only 1 to 2 months (Hafez, 1952; Pfeffer, 1967; Garel et al., 2005; Tornero et al., 2016). Although the affiliation between the European mouflon and the domestic sheep's wild ancestor is not straightforward due to a complex history of fertilization and hybridization between wild and domestic populations (Poplin, 1979; Schröder et al., 2016), the European mouflon remains the closest living representative of early domestic breeds. A 3- to 4-month period is also longer than what was observed in the 8th millennium BC domestic sheep in the Near East (Tornero et al., 2016), while it is shorter than what is observed in most improved breeds (Hafez, 1952). This corroborates the idea that domestication led to an extension of the period of sexual activity in sheep (Hafez, 1952), but also that this trend was accentuated over the long term.

Some individuals escaped the rule. The outliers at Cheia and Hârşova reflect out-of-season births. In both instances they occur $\sim 4$ to 6 months later than the latest births from the main group. Out-of-season breeding is observed today in some herds where a few females happen to present sexual receptivity at a time when the remaining ewes are in sexual rest. The capability of breeding out of season differs according to the sheep breed (Thimonier and Mauléon, 1969; Thimonier et al., 2000). Our results suggest that this trait already existed in the 5th millennium BC sheep herds, and that these lambs born out of season survived in a context of prehistoric husbandry.

\section{Variations with latitude}

A later onset of the breeding season in the higher latitude sites (Orkney) compared with the middle latitudes sites (central/southeastern Europe and France) also meets current expectations. Currently, later lambing is observed at higher latitudes, where the photoperiodic cycle induces shorter periods and a later onset of sexual activity in the ewe (Hafez, 1952). In middle latitude locations in Europe, the onset of the sheep's breeding season is in September with lambing occurring from February onwards. In contrast to this, present day ewes established in Orkney do not give birth until April/ May. Similarly, the Soay sheep from the neighbouring archipelago of St Kilda, Outer Hebrides, does not start breeding until November and gives birth from April onwards (Blackbourn, 1995). Considering that the Knap of Howar farm constitutes the earliest occurrence to date of sheep in Orkney, a later onset of the breeding season would suggest rapid adaptation to the photoperiodic conditions of North Atlantic Europe.

The harsh winter conditions and consequences on neonatal survival (McCormick, 1998) might also explain some of the data set. At the Holm of Papa Westray, foetuses and neonatal individuals are extremely abundant (Tresset, 2003, Balasse and Tresset, 2009; and Supplementary Material S1). A shorter birth distribution, with a later onset compared with middle latitude sites, could reflect the non-representation of the earliest births: the second and third molars' formation is completed later in life (Weinreb and Sharav, 1964; Milhaut and Nézit, 1991), consequently the sample does not include neonatal or infantile mortality.

\section{The season of birth}

The season of birth is determined by comparison with the modern $\mathrm{M} 2$ reference set (Figure 3). The slight disagreement between the KMZ and ROU data sets might suggest interbreed variability in the timing of tooth development, which must be confirmed using larger data sets. Caution is required when interpreting these ratios on a monthly scale. At Cheia, Bercy and Collet-Redon, sheep births started in late winter and occurred throughout the spring to early summer. The out-of-season birth at Cheia occurred in late autumn. The assemblage from Cheia, on which analysis was conducted both on the M2 and the M3 (Tornero et al., 2013), may be used to fix the period of birth in the M3 data set, until strong reference sets are obtained for the M3. On all sites from the central/southeastern Europe group, sheep births occurred from late winter to early summer, possibly with a slightly earlier onset at Alsónyék (Figure 4). A late winter onset of the lambing season is also in agreement with the very first reference point obtained from the M3 of a Kemenez sheep born in February (Figure 4).

\section{Temporal changes at the regional scale}

When comparing results on a supra-regional scale, no diachronic trend is observed: the Chalcolithic sheep at Cheia (turn of 5th millennium BC), Borduşani and Hârşova (second half of 5th millennium BC) all had very similar birth periods, comparable with those of the Early Neolithic sheep at Măgura (early 6th millennium BC).

Inter-site variability within the Orkney group is interesting in several respects: first, because the Knap of Howar represents the earliest adaptation of sheep husbandry on the islands, whereas the settlements at Skara Brae and Holm of Papa Westray postdate it by several centuries; second, because a major adaptation of sheep husbandry systems occurred within the first millennia of their presence on these islands. This adaptation consisted of the introduction of seaweed to the sheep's diet in winter, in order to cope with the scarcity of vegetation. Today, the sheep from the North Ronaldsay breed, endemic to Orkney, survive on a diet composed almost exclusively of seaweed, which they became adapted to after being confined to the shoreline 
since the building of a dyke encircling the island in the 1830s. These sheep attain optimal weight in winter, a time of the year when large amounts of kelp are driven ashore by storms (Fenton, 1978). In spite of this, lambing time is scheduled for late spring (April/May). The investigation of seaweed consumption by sheep in the archaeological record, involving stable carbon isotope analysis, has demonstrated no contribution of seaweed to the sheep's diet in the early stages of husbandry at the Knap of Howar, but a significant and systematic contribution of seaweed to the sheep's winter diet at the Holm of Papa Westray (Balasse et al., 2006; Balasse and Tresset, 2009). At Skara Brae, seaweed consumption is not attested to the earliest phase of occupation; however, it is detected in the second phase of occupation, where it occurred in the winter, though not on a systematic basis (Balasse et al., unpublished). Considering this nutritional parameter, it does not seem that the breeding period was different at the Knap of Howar before the introduction of a seaweed complementation in winter, whereas no change was observed within the Skara Brae assemblage before or after the first appearance of this practice (Figure 4). This would suggest that a major change in food availability throughout the annual cycle did not significantly impact the cycle of sheep fertility.

\section{Conclusion}

Of the sample set considered, zooarchaeology confirms the expected scheme of lambing over a restricted time of the year in European sheep from the 6th to 3rd millennia BC. A 3- to 4-month breeding season, longer than in the present day European mouflon and shorter than in current improved breeds, corroborates the idea that over the long term, domestication led to an extension of the period of sexual activity in sheep.

All conclusions are in agreement with what is currently known of animal physiology in present day sheep. Beyond the historical significance, this consistency contributes in reinforcing the methodological basis of the approach. Further studies should enable the definition of variability attributable to technical choices, within global schemes constrained by environmental and climatic factors. These choices should be understood with regards to the orientation of animal productions. Those include in particular milk, which was exploited from the earliest times of sheep husbandry (Helmer et al., 2007).

The capacity for out-of-season breeding, observed in today's Mediterranean breeds, also deserves attention. From the archaeological data set, the occurrence of outliers, reflecting the survival to adulthood of out-of-season lambs, suggests that this trait already existed in the 5th millennium $B C$ sheep herds. Could this have been a starting point for the emergence, through selection, of sheep breeding out of season? Future research may help clarifying this point.

\section{Acknowledgements}

The authors thank Allison Sheridan and the National Museums Scotland for permission to sample the Skara Brae sheep, and
Anett Osztás and István Zalai-Gaál who led the excavations at Alsónyék-Bátaszék. The authors also thank Soizic and David Cuisnier from the Ferme insulaire de Kemenez for providing access to their property and sheep. Over the last 12 years, this work has been supported by an ECLIPSE II project 2004-2005 (dir. A.T. and M.B.) for the study of Knap of Howar, Holm of Papa Westray, Bercy and the Carmejane sheep; by funds from the SRA Provence-Alpes-Côte d'Azur to E.B. for the study of Collet-Redon; by a NERC project (NER/ B/S/2003/00223, dir. I. Mainland) for the study of the Rousay sheep; the 'SIANHE' ERC Starting Grant project (GA 202881, dir. M.B.) for the study of the remains from Măgura, Cheia, Borduşani-Popină, Hârşovatell, Skara Brae, Rousay and Kemenez; by the CNCS - UEFISCDI project PN-II-ID-PCE-2011-3-1015 (dir. A.B.) for the study of the Romanian assemblages; and by the DFG Food Cultures project (IV 101/5-1, dir. M.I.) for the study of the material from Alsónyék-Bátaszék. The authors also thank Philippe Chemineau for his interest in our research and enlightening discussions. English language editing by Jill Cucchi.

\section{Supplementary material}

To view supplementary material for this article, please visit https://doi.org/10.1017/S1751731117001045

\section{References}

Balasse $M$, Bălăşescu A, Janzen A, Ughetto-Monfrin J, Mirea P and Andreescu R 2013. Early herding at Magura-Boldul lui Mos Ivanus (early sixth millennium BC, Romania): environments and seasonality from stable isotope analysis. European Journal of Archaeology 16, 221-246.

Balasse M, Bălăşescu A, Tornero C, Frémondeau D, Hovsepyan R, Gillis R and Popovici D 2017. Investigating the scale of herding in Chalcolithic pastoral communities settled by the Danube river in the 5th millennium BC: a case study at Borduşani-Popină and Hârşova-tell (Romania). Quaternary International, 436 Part B, 29-40.

Balasse M, Boury L, Ughetto-Monfrin J and Tresset A 2012a. Stable isotope insights $\left(\delta^{18} 0, \delta^{13} \mathrm{C}\right)$ into cattle and sheep husbandry at Bercy (Paris, France, IV millennium $\mathrm{BC}$ ): birth seasonality and winter leaf foddering. Environmental Archaeology 17, 29-44.

Balasse M, Obein G, Ughetto-Monfrin J and Mainland I 2012b. Investigating seasonality and season of birth in past herds: a reference set of sheep enamel stable oxygen isotope ratios. Archaeometry 54, 349-368.

Balasse M, Smith AB, Ambrose SH and Leigh SR 2003. Determining sheep birth seasonality by analysis of tooth enamel oxygen isotope ratios: the Late Stone Age site of Kasteelberg (South Africa). Journal of Archaeological Science 30, 205-215. Balasse $M$, Tornero C, Bréhard S, Ughetto-Monfrin J, Voinea V and Bălăşescu A 2014. Cattle and sheep herding at Cheia, Romania, at the turn of the fifth millennium cal BC: a view from stable isotope analysis. In Early farmers: the view from archaeology and science (ed. A Whittle and P Bickle), pp. 115-142. Oxford University Press, Oxford, UK.

Balasse $M$ and Tresset A 2007. Environmental constraints on reproductive activity of domestic sheep and cattle: what latitude for the herder? Anthropozoologica 42, 71-88.

Balasse M and Tresset A 2009. A key to the adaptation of Neolithic husbandry in the Orkneys: contribution of seaweed to the sheep diet at the Holm of Papa Westray, revealed through stable isotope analysis $\left(\delta^{13} \mathrm{C}\right.$ and $\left.\delta^{18} 0\right)$ of teeth. In On the fringe of Neolithic Europe. Excavation of a chambered cairn on the Holm of Papa Westray, Orkney (ed. A Ritchie), pp. 74-82. Society of Antiquaries of Scotland, Edinburgh, Scotland.

Balasse M, Tresset A and Ambrose SH 2006. First evidence for seaweed winter foddering in the Neolithic of Scotland. Journal of Zoology 270, 170-176. 


\section{Balasse, Tresset, Bălăşescu, Blaise, Tornero, Gandois, Fiorillo, Nyerges, Frémondeau, Banffy and Ivanova}

Blackbourn D-R 1995. Le mouton de Soay et son environnement sur l'île de Hirta (archipel de St Kilda, Ecosse). Journal d'Agriculture traditionnelle et de Botanique Appliquée, nouvelle série 37, 89-118.

Blaise $E$ and Balasse M 2011. Seasonality and season of birth of modern and late Neolithic sheep from south-eastern France using tooth enamel $\delta^{18} 0$ analysis. Journal of Archaeological Science 38, 3085-3093.

Bryant JD, Froelich PN, Showers WJ and Genna BJ 1996. Biologic and climatic signals in the oxygen isotopic composition of Eocene-Oligocene equid enamel phosphate. Palaeogeography, Palaeoclimatology, Palaeoecology 126, 75-90.

Chemineau P, Guillaume D, Migaud M, Thiéry JC, Pellicer-Rubio MT and Malpaux B 2008. Seasonality of reproduction in mammals: intimate regulatory mechanisms and practical implications. Reproduction in Domestic Animals supplement 2, 40-47.

D'Angela D and Longinelli A 1990. Oxygen isotopes in living mammal's bone phosphate: further results. Chemical Geology: Isotope Geoscience section 86, 75-82.

Dacheux JL, Pisselet C, Blanc MR, Hochereau-de-Revier MT and Courot M 1981. Seasonal variations in rete testis fluid secretion and sperm production in different breeds of ram. Journal of Reproduction and Fertility 61, 363-371.

Digard J-P 1981. Techniques des nomades Baxtyâri d'Iran. Editions de la Maison des Sciences de I'Homme, Paris, France.

Fenton A 1978. The Northern Isles: Orkney and Shetland. Tuckwell Press, Edinburgh, Scotland.

Fricke HC and O'Neil JR 1996. Inter- and intra-tooth variation in the oxygen isotope composition of mammalian tooth enamel phosphate: implications for palaeoclimatological and palaeobiological research. Palaeogeography, Palaeoclimatology, Palaeoecology 126, 91-99.

Garel M, Cugnasse J-M, Gaillard J-M, Loison A, Gibert P, Douvre P and Dubray D 2005. Reproductive output of female mouflon (Ovis gmelini musimon x Ovis sp.): a comparative analysis. Journal of Zoology, London 266, 65-71.

Hafez ESE 1952. Studies on the breeding season and reproduction of the ewe Part I. The breeding season in different environments. Part II. The breeding season in one locality. Journal of Agricultural Science 42, 189-231.

Handley LI, Byrne K, Santucci F, Townsend S, Taylor M, Bruford MW and Hewitt GM 2007. Genetic structure of European sheep breeds. Heredity 99, 620-631.

Helmer D, Gourichon L and Vila E 2007. The development of the exploitation of products from Capra and Ovis (meat, milk and fleece) from the PPNB to the Early Bronze in the northern Near East (8700 to 2000 BC cal.). Anthropozoologica 42, 41-69.

IAEA/WMO 2016. Global network of isotopes in precipitation. The GNIP database. Retrieved from http://www.iaea.org/water

Karsch FJ, Bittman EL, Foster DL, Goodman RL, Legan SJ and Robinson JE 1984. Neuroendocrinal basis of seasonal reproduction. Recent Progress in Hormone Research 40, 185-232.

Land LS, Lundelius EL and Valastro S 1980. Isotopic ecology of deer bones. Palaeogeography, Palaeoclimatology, Palaeoecology 32, 143-151.

Malpaux B, Viguié C, Skinner DC, Thiéry JC and Chemineau P 1997. Control of the circannual rhythm of reproduction by melatonin in the ewe. Brain Research Bulletin 44, 431-438.

Martin GB, Oldham CM, Cognié $Y$ and Pearce DT 1986. The physiological response of anovulatory ewes to the introduction of rams - a review. Livestock Production Science 15, 219-247.

McCormick F 1998. Calf slaughter as a response to marginality. In Life on the edge: human settlements and marginality (ed. CM Mills and G Coles) pp. 49-51. Oxbow, Oxford, UK.
Meadows JR, Cemal I, Karaca O, Gootwine E and Kijas JW 2007. Five ovine mitochondrial lineages identified from sheep breeds of the Near East. Genetics 175, 1371-1379.

Milhaud G and Nézit J 1991. Développement des molaires chez le mouton. Etude morphologique, radiographique et microdurométrique. Recueil de Médecine Vétérinaire 167, 121-127.

Peters A, von den Driesch A and Helmer D 2005. The upper Euphrates-Tigris basin: Cradle of agropastoralism?. In First steps of animal domestication. New archaeozoological approaches (ed. J-D Vigne, J Peters and D Helmer), pp. 96-124. Oxbow, Oxford, UK.

Pfeffer P 1967. Le Mouflon de Corse: position systématique, écologie et éthologie comparées. Mammalia 31. De Gruyter, Paris, France.

Poplin F 1979. Origine du Mouflon de Corse dans une nouvelle perspective paléontologique, par marronnage. Annales de génétique et de sélection animale 11, 133-143.

Rozanski K, Araguas-Araguas L and Gonfiantini R 1993. Isotopic patterns in modern global precipitation. In Climate Change in Continental Isotope Records (ed. PK Stwart, KC Lohmann, J McKenzie and S Savin), pp. 1-36. American Geophysical Union, Washington, MD, USA.

Schröder O, Lieckfeldt D, Lutz W, Rudloff C, Frölich K and Ludwig A 2016. Limited hybridization between domestic sheep and the European mouflon in Western Germany. European Journal of Wildlife Research $62,307$.

Thiéry JC, Chemineau P, Hernandez X, Migaud M and Malpaux B 2002. Neuroendocrinal interactions and seasonality. Domestic Animal Endocrinology 23, 87-100.

Thimonier J 1981. Control of seasonal reproduction in sheep and goats by light and hormones. Journal of Reproduction and Fertility. Supplement 30, 33-45.

Thimonier J, Cognié Y, Lassoued N and Khaldi G 2000. L'effet mâle chez les ovins: une technique actuelle de maîtrise de la reproduction. INRA Productions animales 13, 223-231.

Thimonier J and Mauléon P 1969. Variations saisonnières du comportement d'oestrus et des activités ovarienne et hypophysaire chez les ovins. Annales de Biologie animale, Biochimie, Biophysique 9, 233-250.

Tornero C, Bălăşescu A, Ughetto-Monfrin J, Voinea V and Balasse M 2013. Seasonality and season of birth in early Eneolithic sheep from Cheia (Romania): methodological advances and implications for animal economy. Journal of Archaeological Science 40, 4039-4055.

Tornero C, Balasse M, Molist M and Sana M 2016. Seasonal reproductive patterns of early domestic sheep at Tell Halula (PPNB, Middle Euphrates Valley): evidence from sequential oxygen isotope analyses of tooth enamel. Journal of Archaeological Science: Reports 6, 810-818.

Tresset A 2003. French connections II: of cows and men. In Neolithic settlement in Ireland and western Britain (ed. I Armit, E Murphy, EL Nelis and DDA Simpson), pp. 18-30. Oxbow Books, Oxford, UK.

Tresset A and Vigne J-D 2011. Last hunter-gatherers and first farmers of Europe. Comptes Rendus Biologies 334, 182-189.

Vigne J-D, Balasse M, Gourichon L, Helmer D, Lesur J, Mashkour M, Tresset M and Vila E 2012. Etats des connaissances archéozoologiques sur les débuts de l'élevage du mouton dans l'ancien monde. Ethnozootechnie 91, 11-19.

Weinreb MM and Sharav DMD 1964. Tooth development in sheep. American Journal of Veterinary Research 25, 891-908. 